\title{
Novelties in Russula: R. olivobrunnea, R. intermedia and R. groenlandica
}

\author{
JUHANI RUOTSALAINEN and JUKKA VAURAS
}

\begin{abstract}
RUOTSALAINEN, J. \& VAURAS, J. 1994: Novelties in Russula: R. olivobrunnea, R. intermedia and R. groenlandica. - Karstenia 34:21-34. ISSN 0453-3402

Russula olivobrunnea Ruots. \& Vauras is described as a new species, known from Finland, Sweden, Norway and Austria. Its distribution in Fennoscandia is mapped, and its ecology and relationships are discussed. It is a boreal species growing with Picea abies in moist herb-rich forests. A neotype is selected for $R$. intermedia P. Karst., which is an older, legitimate name for the well-known species $R$. lundellii Singer. The distribution of $R$. intermedia in Finland is mapped. The new name $R$. groenlandica Ruots. \& Vauras is proposed for $R$. claroflava var. viridis Knudsen \& T.Borgen. The importance of examining pileipellis characteristics with the reagent fuchsin is emphasized, even those of the acrid yellow-spored Russula species.
\end{abstract}

Key words: Agaricales, Basidiomycetes, Fennoscandia, Picea abies, Russula claroflava, $R$. fusconigra, $R$. groenlandica, $R$. intermedia, $R$. lundellii, $R$. olivobrunnea, taxonomy

Juhani Ruotsalainen, Metsätie 12 A 4, FIN-71310 Vehmersalmi, Finland Jukka Vauras, Herbarium, Department of Biology, Abo Akademi University, FIN-20500 Turku, Finland

\section{Introduction}

Recently we described (Ruotsalainen \& Vauras 1990) two new Russula species growing in moist boreal spruce forests. A Russula with ecology and Finnish distribution similar to Russula olivina Ruots. \& Vauras, and sometimes sharing growth sites with that species, is described here as the new species $R$. olivobrunnea. Further, we publish the results of our type studies on $R$. fusconigra M.M.Moser, $R$. intermedia P. Karst., $R$. aurantiolutea Kauffman and $R$. claroflava var. viridis Knudsen \& T.Borgen.

\section{Material and methods}

To find specimens of Russula olivobrunnea in herbarium material, we studied specimens filed as R. fusconigra in IB, as $R$. mollis in PRM, as $R$. olivascens in $\mathrm{H}, \mathrm{KUO}, \mathrm{M}, \mathrm{O}$, OULU, PRM, S, TAA, TUR and UPS, and as $R$. fusconigra, $R$. integra and $R$. nauseosa in $\mathrm{H}, \mathrm{KUO}, \mathrm{OULU}$,
TAA and TUR. In addition, most Russula spp. in H, KUO, OULU, TAA and TUR were checked. All specimens of $R$. intermedia, mostly filed as $R$. lundellii, rarely as $R$. mesospora, were examined in $\mathrm{H}$, JOE, Joensuu Research Station, JYV, KUO, OULU, TUR and TURA. To find specimens of $R$. groenlandica, we checked all available specimens of $R$. claroflava var. viridis from $C, R$. clarofava from TUR and the greenish specimens of $R$. claroflava from O (the symbols according to Holmgren et al. 1990).

The colours of fresh specimens were compared with those in Küppers (1981) and Cailleux (1981). Spore masses from spore prints were placed between microscope slides and colour matched against the colour chart prepared by C. Dagron (Paris). Spores were studied and drawn in Melzer's reagent, and dermatocystidia of pileipellis, taken about half way between the margin and the centre, were studied and drawn from material treated with fuchsin and $5 \%$ hydrochloric acid and mounted in water. Other microscopical characters were drawn in $10 \%$ $\mathrm{NH}_{4} \mathrm{OH}$, after staining with Congo Red. The spores were measured excluding the ornamentation, and the basidia lengths excluding the sterigmata. Soil samples were collected from the humus layer to a depth of $10 \mathrm{~cm}$ and analysed by Soil Analysis Service Ltd. (Finland). 

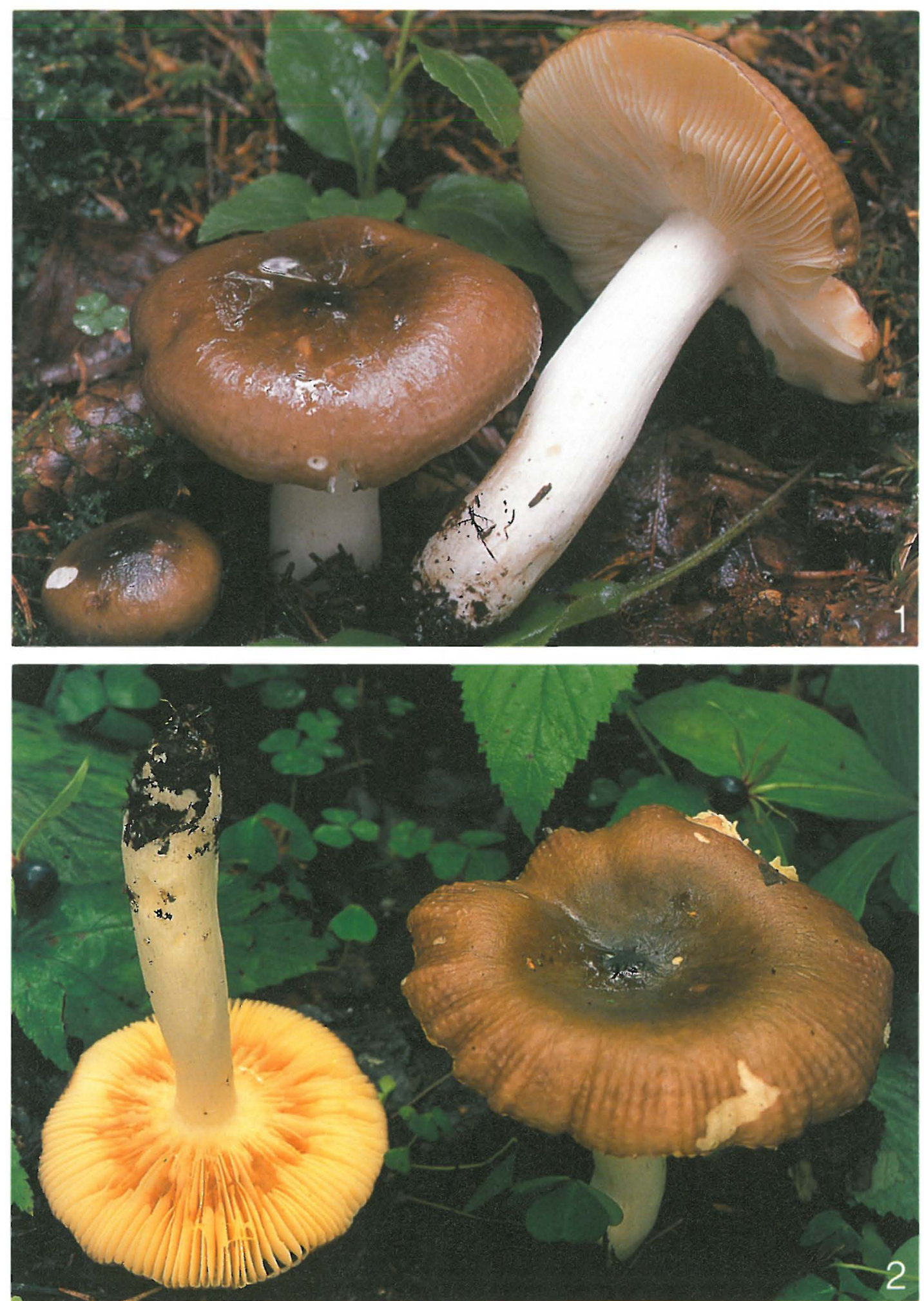

Figs. 1-2. Russula olivobrunnea, photographed in situ. - 1: Young fruit bodies in rainy weather, x 0.9 (Ruotsalainen $2756 F$, KUO). - 2: Mature fruit bodies, x 0.8 (type). Photographs Juhani Ruotsalainen (1), Jukka Vauras (2). 
Russula olivobrunnea Ruots. \& Vauras, spec. nova - Figs. 1-7

Species media, pileo 3-18 cm lato, convexo, dein depresso, multicolore, saepe centro subnigro vel viridifusco et margine vinosobrunneo, margine obtuso et sulcato. Lamellae cremeae, postea flavescentes. Stipes $6-13 \mathrm{~cm}$ longus, $1-2.5 \mathrm{~cm}$ crassus, albus. Carne alba, odore indistincto, sapore miti. Sporae in cumulo flavae (Romagnesi IVd), 9$12 \times 7.5-10.5 \mu \mathrm{m}$, verruculosae, verrucis usque ad $1.5 \mu \mathrm{m}$ altis. Basidia 4-sporigera, 37-71 x 13-20 $\mu \mathrm{m}$. Cystidia hymenii $65-115 \times 10-19 \mu \mathrm{m}$. Cutis cum dermatocystidiis 3-12 $\mu \mathrm{m}$ latis. Habitatio: plerumque in silva calcarea in propinquitatem Picearum (Picea abies).

Type: Finland. Perä-Pohjanmaa: Rovaniemi rural municipality, Jaatila, Jaatilanvaara, Savioja, herb-rich mixed forest, by a brook, with Picea abies, Betula, Populus tremula, Alnus incana, Prunus padus, Actaea erythrocarpa, A. spicata, Filipendula ulmaria, Oxalis acetosella, Paris quadrifolia, Grid $27^{\circ}$ E: $73490: 4266$, alt. 87 m, 19.VIII.1992 Juhani Ruotsalainen \& Jukka Vauras $6877 F$ (TURA 2606, holotype; KUO, isotype).

Pileus (3-)5-11(-18) cm in diam, first convex, soon depressed at centre, mixed of various colours, centre blackish, brown-black (Küppers S90Y20M30), dark brown (Y99M70C80), yellowred-brown, green-brown (Y70M60C80, Cailleux 67R), brown-green (Y70M50C60, 77R, 89R), yellow-brown-greenish (Y70M30C30), greenish (Y99M50C70), margin red-brown (49R), yellowred-brown (Y50M40C30), black-red-brown (Y99M70C80), dirty brown (Y50M40C40), brown-red, dirty brown-violet (35R, 25R), violet (Y50M60C60), yellow-green, blunt, sometimes undate, when young smooth, soon sulcate (up to 2 $\mathrm{cm}$ ); surface shining when dry, viscid when moist, not pruinose, somewhat uneven, half of pileipellis peeling.

Lamellae normally crowded, thin, up to 16 $\mathrm{mm}$ broad, first cream coloured, later yellow (S00Y30M10), some forking at stipe apex, interveined, margin even, often up to $3 \mathrm{~mm}$ brown-red at pileus margin, no lamellulae; taste mild.

Stipe 6-13 cm long, $1-2.5 \mathrm{~cm}$ wide, mostly subclavate, longitudinally rugulose, not pruinose, base rounded; white, sometimes slightly brown at base when old, in exsiccatae mostly with pale brown tint; flesh in stipe moderately firm, spongy inside.

Context white, not colouring when cut, under pileipellis whitish to pale red-brown; $\mathrm{FeSO}_{4}$ gradually turning stipe red-brown, guaiacol fairly rapidly brown-red. Smell indistinct. Taste mild.

Spores in mass yellow (Romagnesi IVd), (9-)9.5$11.5(-12) \times(7.5-) 8-9.5(-10.5) \mu \mathrm{m}$, total range of mean values $10.0-10.9 \times 8.2-9.2 \mu \mathrm{m}, \overline{\mathrm{x}}=10.4 \times 8.6 \mu \mathrm{m}$ ( 5 collections, 100 spores), $Q=(1.1-) 1.15-1.3$, the average Q of 5 collections 1.22 , warts large and isolated, cylindrical to cone-shaped, up to $1.5 \mu \mathrm{m}$ high, plage moderately amyloid, apiculus fairly small.

Basidia 37-71 x 13-20 $\mu \mathrm{m}$, clavate, 4spored. Hymenial cystidia $65-115 \times 10-19 \mu \mathrm{m}$, blunt, acute or appendiculate.

Apical cells of pileipellis 1-4 $\mu \mathrm{m}$ broad, cylindrical or tapering to apex. Dermatocystidia moderately abundant, 3-12 um broad, 0-3 septate, cylindrical to clavate, often with small lateral knobs, without encrusted elements.

\section{Distribution, ecology and phenology}

Russula olivobrunnea is a fairly demanding, calciphilous species. In Finland it is found in eutrophic forests, with a distribution extending from the SW part of the country (Hemiboreal zone) up to Lapland (Northern Boreal zone), but concentrated in the northern part of the country (Fig. 5). The localities in Sweden and Norway are comparable with those in Finland. According to the label, the Austrian specimen was found in "saurer Nadelwald", but in parentheses there is an addition "genauer Standort nicht ermittelbar". This specimen was found among the material loaned from IB filed as $R$. fusconigra M.M.Moser.

$R$. olivobrunnea is typically a species of rich grass-herb forests dominated by Picea abies (Fig. 6), and Picea is its probable mycorrhizal host. Other trees recorded at the sites of $R$. olivobrunnea include Alnus incana, Betula, Populus tremula, Salix caprea, Prunus padus and Pinus sylvestris. Most growing sites of the species are moist, e.g. brook-sides and slope depressions with moving nutrient-rich water. In the southernmost Finnish locality in Paimio municipality, $R$. olivobrunnea was found at the margins of an abandoned limestone quarry. Typical herbs at the sites of $R$. olivobrunnea include Oxalis acetosella, Paris quadrifolia and Rubus saxatilis. Often it grows in the same locality with the rare and threatened orchids Calypso bulbosa and Cypripedium calceolus. In fact, many localities of $R$. olivobrunnea in Fin- 

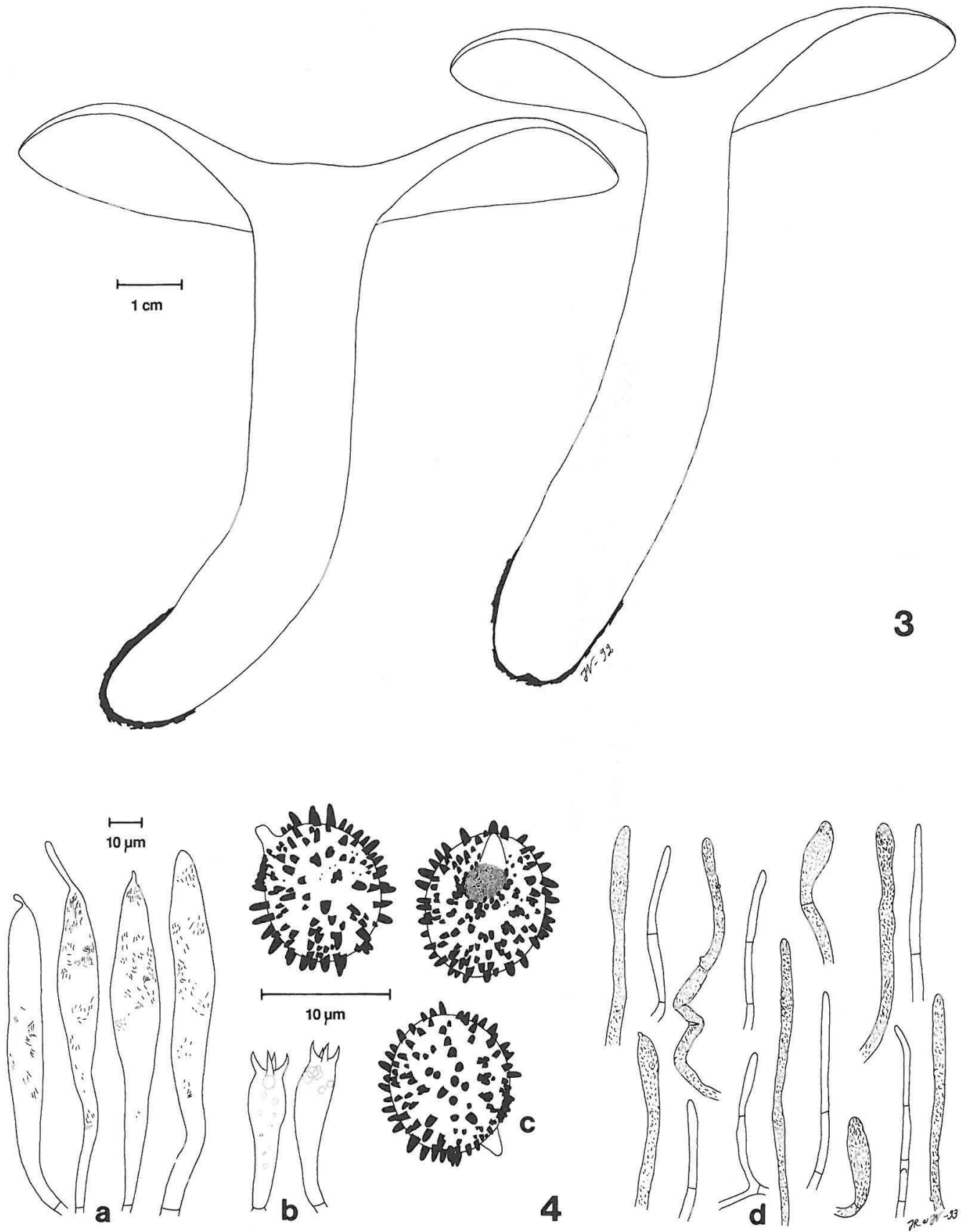

Figs. 3-4. - 3: Fruit bodies of Russula olivobrunnea, x 1 (type). - 4a-d: Microscopical details of Russula olivobrunnea (from type). a) hymenial cystidia, b) basidia, c) spores, d) elements of pileipellis. Scales: spores x 2000, others x 500 


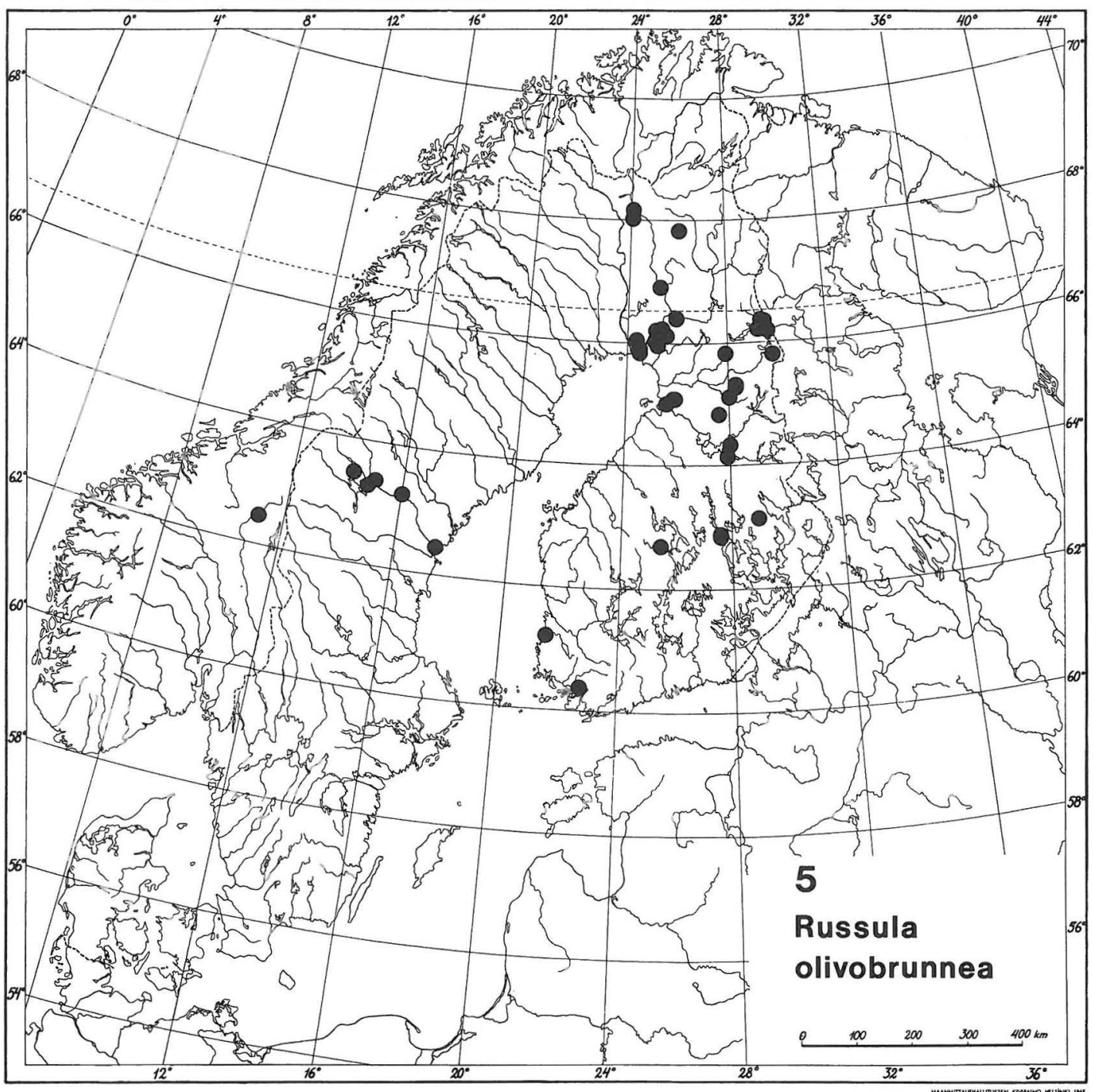

Fig. 5. Distribution of Russula olivobrunnea in Fennoscandia according to the material examined.

land are included in the national protection programme for herb-rich forests.

Fungi sharing localities with $R$. olivobrunnea include Calocybe onychina (Fr.) Donk, Gerronema prescotii (Weinm.) Redhead, Inocybe armeniaca Huijsman, I. leucoblema Kühner, I. maculata Boud., I. muricellata Bres., I. nitidiuscula (Britzelm.) Sacc., Lactarius deterrimus Gröger, $L$. scrobiculatus (Scop.: Fr.) Fr., L. zonarioides Kühner \& Romagn., Russula nauseosa (Pers.) Fr., $R$. olivina Ruots. \& Vauras, $R$. postiana Romell, $R$. queletii Fr., R. firmula Jul.Schäff., and Tephrocybe rancidum (Fr.) Singer. The soil $\mathrm{pH}$ of two sites of $R$. olivobrunnea analysed was 5.6 and 6.3. Further soil analysis data are given in Table 1. 


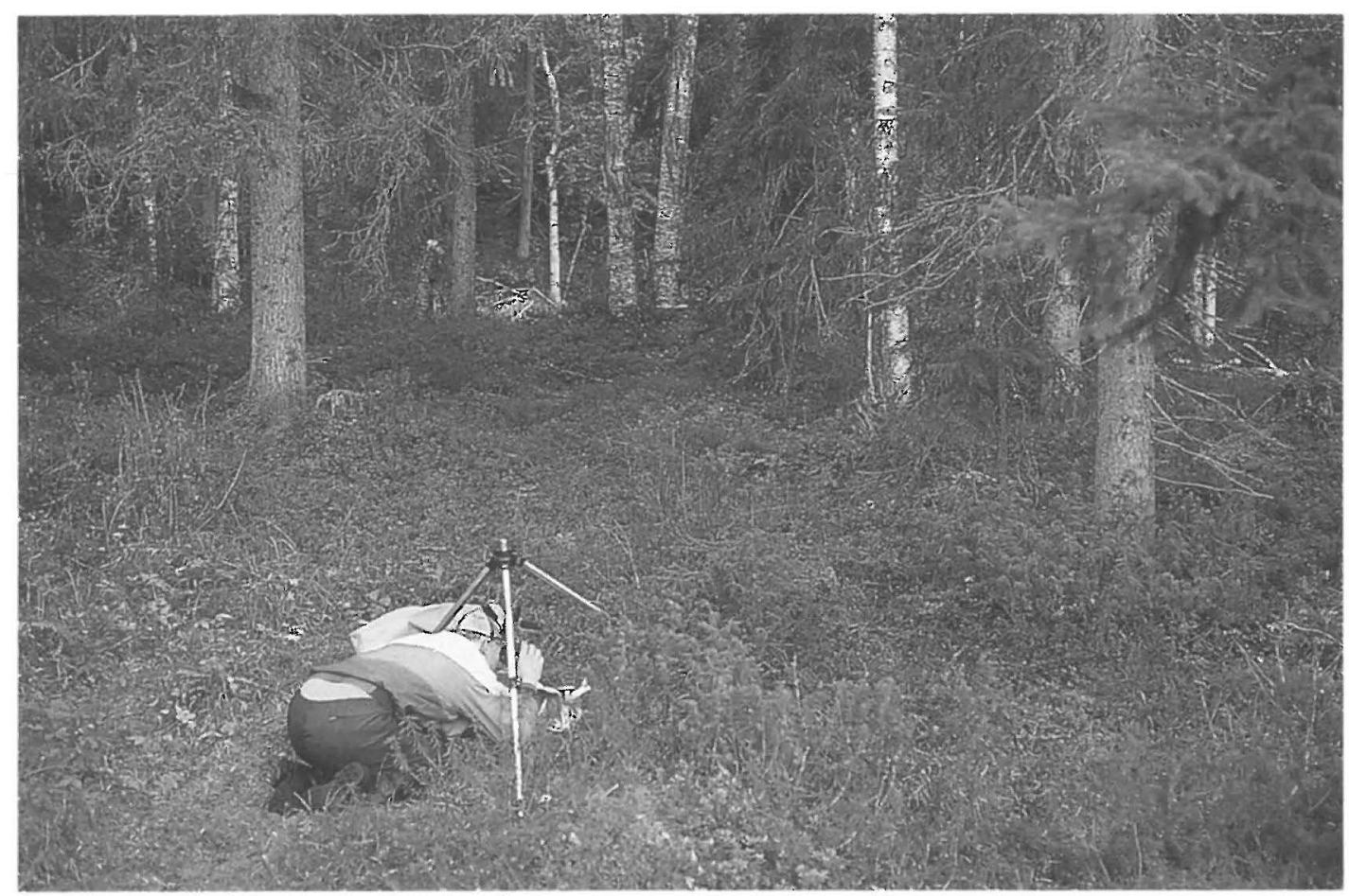

Fig. 6. Growing site of Russula olivobrunnea in Finland, Koillismaa, Kuusamo, Oulanka National Park, S foot of the hill Ampumavaara. Photograph 23.VIII.1992 Jukka Vauras.

In Finland the fruiting period of $R$. olivobrunnea starts in late July, reaching a maximum in mid-August - mid-September, and ceasing in late September - mid-October (Fig. 7). The species has been collected in Finland every year since 1986. According to the number of collections examined, the most favourable years for the fruiting of the species were 1986, 1988 and 1992. Several collections even date from 1987, when the summer was rainy and exceptionally cool.

\section{Specimens examined}

Finland. Varsinais-Suomi: Paimio, Kurki, 1991 Ruuskanen \& Vauras 6230, 6231 (TUR), 1992 Vauras 7575 (TURA, KUO, M, O), 19937577 (TURA, S), 7870 (TURA), 1993 Vauras 9010 (TUR). Satakunta: Rauma rural municipality, Sorkka, 1991 Vauras 6133 (TURA). Pohjois-Häme: Saarijärvi, Linnankylä, 1989 Vauras \& Ruotsalainen 1538 (KUO). Pohjois-Savo: Kuopio, Matkusjärvi, 1986 Ruotsalainen 453 (KUO), 1987 Ruotsalainen 602, $660 a$ (KUO), $660 b$ (TAA), 682b (KUO), $683 F$ (KUO, O, TUR), 708, 827 (KUO), 1988 Vauras \& Ruotsa-

Table 1. Surface soil characteristics at two growing sites of Russula olivobrunnea in Finland. 1) Varsinais-Suomi: Paimio, Kurki, old limestone quarry, 29.IX.1992. 2) Perä-Pohjanmaa: Rovaniemi rural municipality, Jaatila, Savioja (type site), 24.VIII.1991.

\begin{tabular}{llllll}
\hline Growing site & $\mathrm{pH}$ & $\mathrm{Ca} \mathrm{mg} / \mathrm{l}$ & $\mathrm{K} \mathrm{mg} / \mathrm{l}$ & $\mathrm{Mg} \mathrm{mg} / \mathrm{l}$ & $\mathrm{P} \mathrm{mg} / \mathrm{l}$ \\
\hline 1 & 5.6 & 4280 & 99 & 147 & 7 \\
2 & 6.3 & 3150 & 120 & 700 & 7 \\
\hline
\end{tabular}


lainen 1000, Ruotsalainen 1001F, 1147 (KUO), Ruotsalainen \& Vauras $3129 F$ (TURA), Vauras $3131 F$ (TURA, MICH, UPS), 1989 Ruotsalainen 1452, Vauras \& Ruotsalainen 1543, Ruotsalainen 1548 (KUO), Vauras 3777 (TURA), 1990 Ruotsalainen 1866, 1976 (KUO), 1991 Ruotsalainen 2338a (KUO), 1992 Ruotsalainen 2632, 2756F, 2757 (KUO), Vauras 6799 (TURA), 1993 Ruotsalainen 3295 (KUO), Vuorilampi, 1986 Ruotsalainen 411 (KUO). Pohjois-Karjala: Juuka, Polvela, 1993 Ruotsalainen 3323a, 3323b (KUO). Kainuu: Paltamo, Mieslahti, 1988 Kytövuori 88-829 (H); Puolanka, Pihlajavaara, 1990 Kytövuori 90-230 (H), 1992 Kytövuori 92-2162 (H), Suolijärvi, 1988 Kytövuori 88-885, 88-887 (H); Sotkamo, Kontinjoki, 1986 Ulvinen (OULU); Suomussalmi, Kurkikylä, $1992 M$. Ohenoja (OULU). Oulun Pohjanmaa: Kiiminki, Keskikylä, 1970 E. \& M. Ohenoja (OULU), Ulvinen (OULU), 1990 E. Ohenoja (OULU), 1991 Kaukonen et al. (OULU); Oulu, Patamäki, 1988 E. Ohenoja (OULU). Perä-Pohjanmaa: Keminmaa, Kallinkangas, 1986 E. Ohenoja (OULU), (2 ex.) Tammilehto (OULU), 1987 (2 ex.) Tammilehto (OULU), 1989 M. Ohenoja (OULU), 1990 Ulvinen (OULU); Rovaniemi rural municipality, Jaatila, 1990 Vauras 4892 (TURA, C), Meltaus, 1976 Ulvinen (OULU), Taipale, 1988 Kytövuori 88-1482 (H); Tervola, Lehmikumpu, 1978 Ulvinen (OULU), Pahtaoja, 1986 E. Ohenoja \& Vuorinen (OULU), Peura, 1986 Ulvinen (OULU), 1992 Kytövuori 92-1791 (H), Vähäjoki, 1992 Kytövuori 92-1714 (H); Tornio, Kalkkimaa, 1986 (2 ex.) Ulvinen (OULU), 1989 Vauras (KUO), 1992 Höijer 614 (TUR), Runteli, 1992 Kytövuori 92-1908, 92-1909 (H). Koillismaa: Kuusamo, Ampumavaara, 1988 Kytövuori 88-933(H), Ruotsalainen 1137 (KUO), 1992 Vauras \& Ruotsalainen $2722 F, 2723 F$ (KUO), Ruotsalainen \& Vauras 7014 (TURA), Iivaara, 1978 Korhonen \& Tuomikoski 2209 (H), 1993 Ruotsalainen $3202 a F$, $3202 b$ (KUO), Liikasenvaara, 1977 Ulvinen (OULU), Paljakka, 1992 Kytövuori 92-1494, 92-1495 (H), Valtavaara, 1987 Ulvinen (OULU); Taivalkoski, Katajavaara, 1986 E. Ohenoja (OULU), Kylmälä, 1972 E. \& M. Ohenoja (OULU). Kittilän Lappi: Kittilä, Pallasjärvi, 1990 Kytövuori 90-300 (H), Tarpomapää, 1988 Kytövıьori 88-1171 (H). Enontekiön Lappi: Enontekiö, Vuontisjärvi, 1988 Kytövuori 88-1351 (H).

Norway. Hedmark: Tynset, Tolga-Os, Höystad, 1986 Kytövuori 86805 (H).

Sweden. Medelpad: Alnön, Alnö, 1986 Kytövuori 86663 (H); Torp, Tubbo, 1989 Vauras \& Ruotsalainen 1507 (KUO). Jämtland: Lit, Häggenås, Storhögen Högarna, 1989 Kytövuori 89-556 (H); Offerdal, Västerberg, 1982 E. Ohenoja (OULU); Rödön, Ås, Åskott, 1989 Kytövuori 89-534 (H). IB).

Austria. Tirol: Mutters, 1978 Klima (Moser 78-350;

\section{Discussion}

Russula olivobrunnea is an intermediate species between the sections Puellarinae (Singer) Jul. Schäff. and Polychromae Maire. However, as a species closely related to $R$. olivina Ruots. \& Vauras, we prefer to place it in the first-

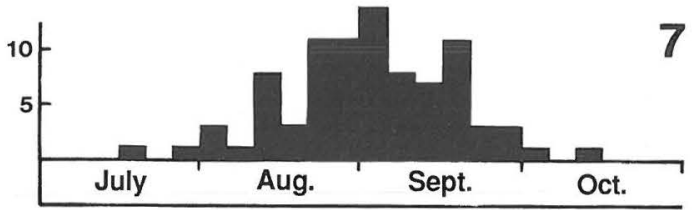

Fig. 7. Fruiting period of Russula olivobrunnea according to the material examined, divided into pentads.

mentioned section, and further in subsection Laricinae (Romagn.) Bon.

The ecology and Nordic distribution of $R$. olivobrunnea and $R$. olivina are fairly similar, and the species are about equally rare. Altough they have much in common in macroscopical and microscopical characters, they also differ in many ways. $R$. olivobrunnea is more robust, the colours of the pileus are darker, the spores are darker in mass (Romagnesi IVd versus $\operatorname{IVb}(-\mathrm{c})$ in $R$. olivina) and basidia are 4-spored. Further, the spores of $R$. olivobrunnea are somewhat smaller and have shorter and broader spines (cf. Ruotsalainen \& Vauras 1990). The pileus of $R$. olivina is characteristically yellow-green to brown-green. However, in 1992, in Kuusamo, Oulanka National Park, Ampumavaara, we saw a few fruit bodies of $R$. olivina that had a reddish tint at the margin of their pileus. Green forms of $R$. olivobrunnea are easily recognized under the microscope by the 4-spored basidia and the ornamentation of spores.

In Finland, R. postiana Romell also grows on rich Picea abies sites, and sometimes in the same forests as $R$. olivobrunnea but on drier sites. In general it has a more southern distribution than $R$. olivobrunnea, but is also known up to Perä-Pohjanmaa (Keminmaa municipality) and Koilismaa (Kuusamo municipality). Typical characters of $R$. postiana, distinguishing it from $R$. olivobrunnea, are the more even and, when dry, more matt pileus; the often inflexed pileus margin; the more orange tinted lamellae; the more pruinose stipe, often with a clear smell of iodoform at base when collected; the smaller spores, often with crests; and the pileipellis with primordial hyphae strongly encrusted. 
$R$. nauseosa (Pers.) Fr. has sometimes been found at the same sites as $R$. olivobrunnea. The fruit bodies of $R$. nauseosa also have a pileus with sulcate margin. However, they are usually smaller and more slender, the spore mass is paler (IVb), and the spores are smaller. $R$. integra (L.) Fr. s. Maire is a more robust species with a southern distribution in Finland.

$R$. fusconigra M.M.Moser differs from $R$. olivobrunnea in the paler (IIIa-c in mass) and somewhat smaller spores $(8-11 \times 6.8-8 \mu \mathrm{m})$, ornamented with a few connections, and in the narrower $(8-12 \mu \mathrm{m})$ hymenial cystidia. According to Moser (1978) the species grows "in silvis coniferis paludosis vel sphagnetis sub Pino silvestri". We have studied the holotype of $R$. fusconigra (Sweden, Småland, Femsjö, E side of the lake Södra Färgen, 28.VIII.1976 M. Moser 76187 (IB)). Drawings of some microscopic characters from the holotype are given (Fig. 8) for comparison and to complete the original description in Moser (1978). In our opinion $R$. fusconigra comes close to $R$. sphagnophila Kauffman, and belongs to the section Puellarinae. $R$. fusconigra has been reported from Finland by Ulvinen et al. (1981) and Korhonen \& Vauras (1986). However, we did not find in Finnish herbaria any specimens fitting to the type of that species.

The acrid species $R$. firmula Jul. Schäff. also has been met in Finland, close to $R$. olivobrunnea in calcareous spruce forests. If not tasted, it may be confused with $R$. olivobrunnea or $R$. postiana. As exsiccatae, $R$. firmula differs from $R$. olivobrunnea in its somewhat smaller spores $(8-10 \times 7-8.5 \mu \mathrm{m})$ with spines in a denser pattern, and in its pileipellis with encrusted pileocystidia. The last is an overlooked character which we have encountered in some taxa of the section Urentinae (Maire) Schäff. We recommend the study of pileipellis with fuchsin instead of or in addition to sulphovanillin as a routine practice in the examination of this section.

\section{Russula intermedia P.Karst. - Figs. 9-11}

Russula intermedia P.Karst., Medd. Soc. Fauna Flora Fennica 16: 38. 1888. - Type: Finland. Tavastia australis: Tammela, Harju, VIII. 1894 P.A. Karsten 3211 (H, neotype; selected here).

Russula aurantiolutea Kauffman, Rep. Michigan Acad. Sci. 11: 81. 1909. - Type: USA. Michigan: Emmet Co., Bay View, 19.IX.1906 C.H. Kauffman (MICH, lectotype; selected by Shaffer 1970, Art. 8.3. (Greuter \& McNeill 1993:209)).

Russula pulcherrima S.Lundell \& Jul.Schäff., Ann. Mycol. 36: 31. 1938, nom illeg. (Art. 64.1., non Russula pulcherrima Velen.). - Type: Sweden. Upland: Upsala, Stadsparken, about $200 \mathrm{~m} \mathrm{~S}$ of Skogshall. Amongst mosses

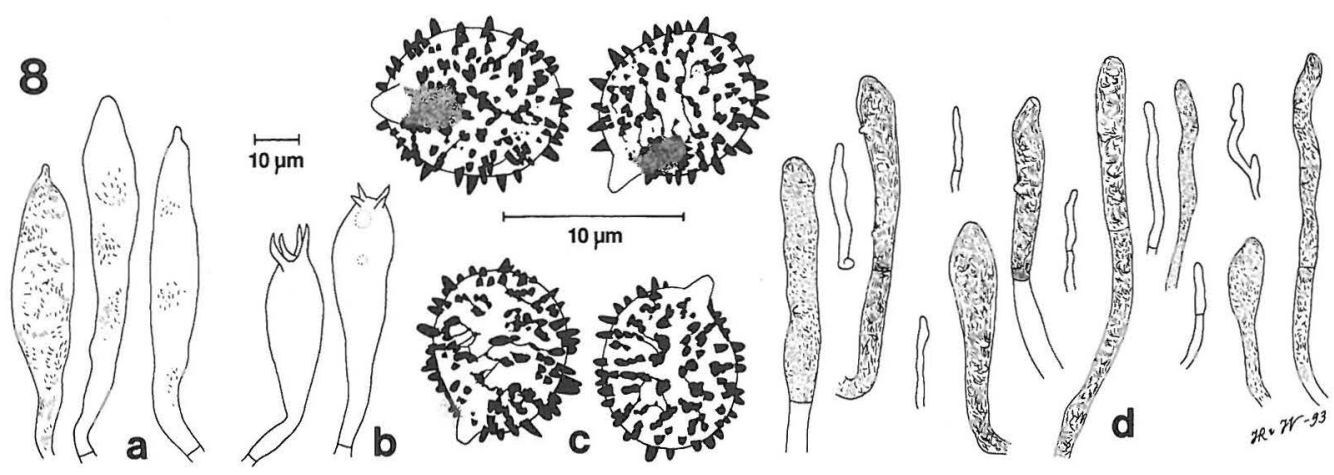

Fig. 8a-d. Microscopical details of Russula fusconigra (from holotype, IB). - a) hymenial cystidia, b) basidium, c) spores, d) elements of pileipellis. Scales: spores x 2000, others x 500 . 
and grasses, Equisetum hiemale and Rubus saxatilis, under birches and mountain-ashes in moist spot in mixed wood, 30.VII. \& 12.VIII.1936 Seth Lundell; Lundell \& Nannfeldt, Fungi Exs. Suec. Ups. 723 (UPS, lectotype; selected here). Russula lundellii Singer, Bull. Soc. Mycol. France 54: 159. 1938. - Type: homotypic with $R$. pulcherrima S. Lundell \& Jul. Schäff.

Russula mesospora Singer, Bull. Soc. Mycol. France 54: 161. 1938. - Type: not existing ?.

P.A. Karsten described only a few new species of the genus Russula. One of those was $R$. intermedia. Unfortunately this name has been nearly completely overlooked. Romagnesi (1967) interpreted it as a synonym to $R$. badia Quél. (with a question mark). The protologue of $R$. intermedia (Karsten 1888) is brief, giving the idea of a yellowspored acrid species, which in Karsten's sense was "inter $R$. emeticam Harz. et $R$. integram Linn. media", growing in SW Finland, the municipality of Tammela "in regione Mustialensi rara". No type material of $R$. intermedia exists in H. Later (Karsten 1891), the same description was published in Swedish. After a further find of the species ("in betuleto prope Harju in Tammela"), Karsten gave a fuller description in 1894 in Swedish and in 1895 in Latin. Fortunately, this last collection, consisting of three fruit bodies matching those of the well-known species $R$. lundellii (cf. Fig. 9), is preserved in fairly good condition in $\mathrm{H}$. There is no disagreement between Karsten's description and the present concept of $R$. lundellii, and the collection is selected here by us to represent the neotype of $R$. intermedia.

The study of the neotype of $R$. intermedia showed the following details. Spores 7-8 × 6-7 $\mu \mathrm{m}$, mean value 7.4 x $6.3 \mu \mathrm{m}, \mathrm{Q}=(1.05-) 1.1-1.25(-$ 1.35), average $\mathrm{Q}=1.17$, subglobose, verruculose, occasionally with some jointure, warts often in rows, blunt, up to $1 \mu \mathrm{m}$ high. Basidia 44-60 × 9-13 $\mu \mathrm{m}$, clavate, 4-spored. Cheilocystidia 9-11 $\mu \mathrm{m}$ broad. Apical cells of pileipellis $2-3 \mu \mathrm{m}$ broad, cylindrical to somewhat clavate, staining in fuchsin. Dermatocystidia 4-10 $\mu \mathrm{m}$ broad, cylindrical, long, rarely septate, pale violet in sulphovanillin.

An excellent description of $R$. intermedia was given by Schäffer (1938) under the name $R$. pulcherrima. However, since that name had been appropriated earlier by Velenovsky'(1920-1922) for another species, Singer (1938) gave the taxon a new name, $R$. lundellii. In the same paper, Singer described a new species, $R$. mesospora, which in our opinion is identical with $R$. intermedia. Schäffer (1938) described the stipe of $R$. pulcherrima as white: "Stipe immer bleibend reinweiss, nie rot". We have often seen $R$. intermedia in Finland in different localities and in abundant occurrences, and have never seen red on the stipes. However, red has been reported on the stipe of $R$. lundellii, at least
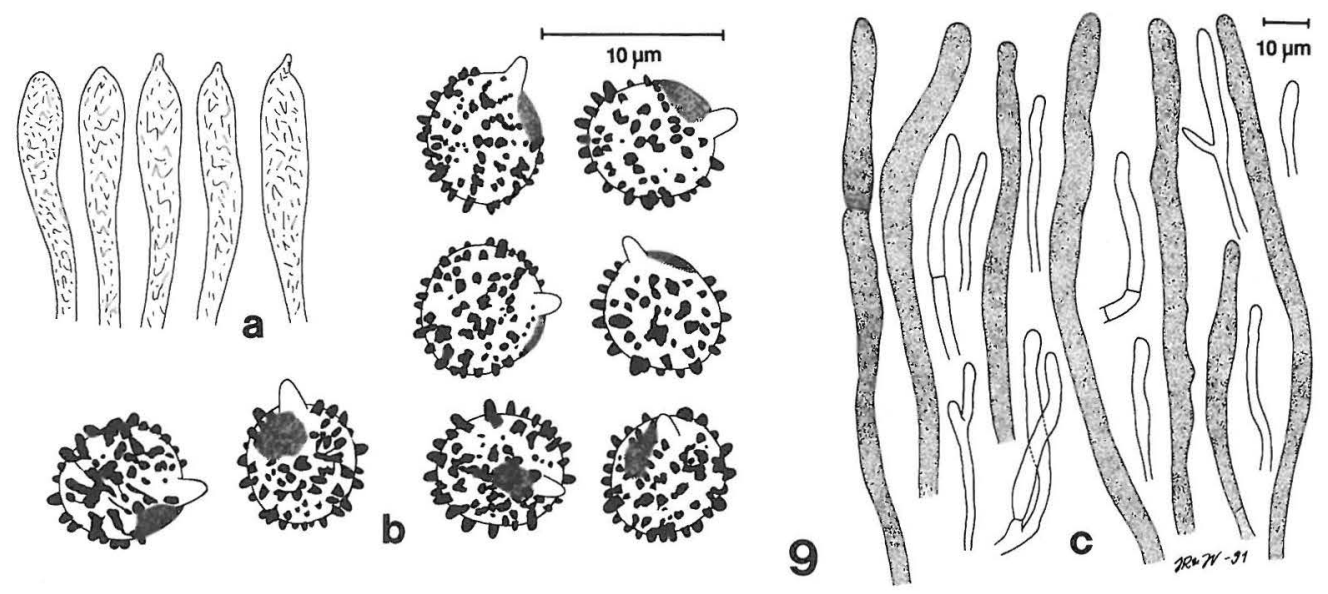

Fig. 9a-c. Microscopical details of Russula intermedia (from neotype, H). - a) hymenial cystidia, b) spores, c) elements of pileipellis. Scales: spores x 2000, others x 500 . 

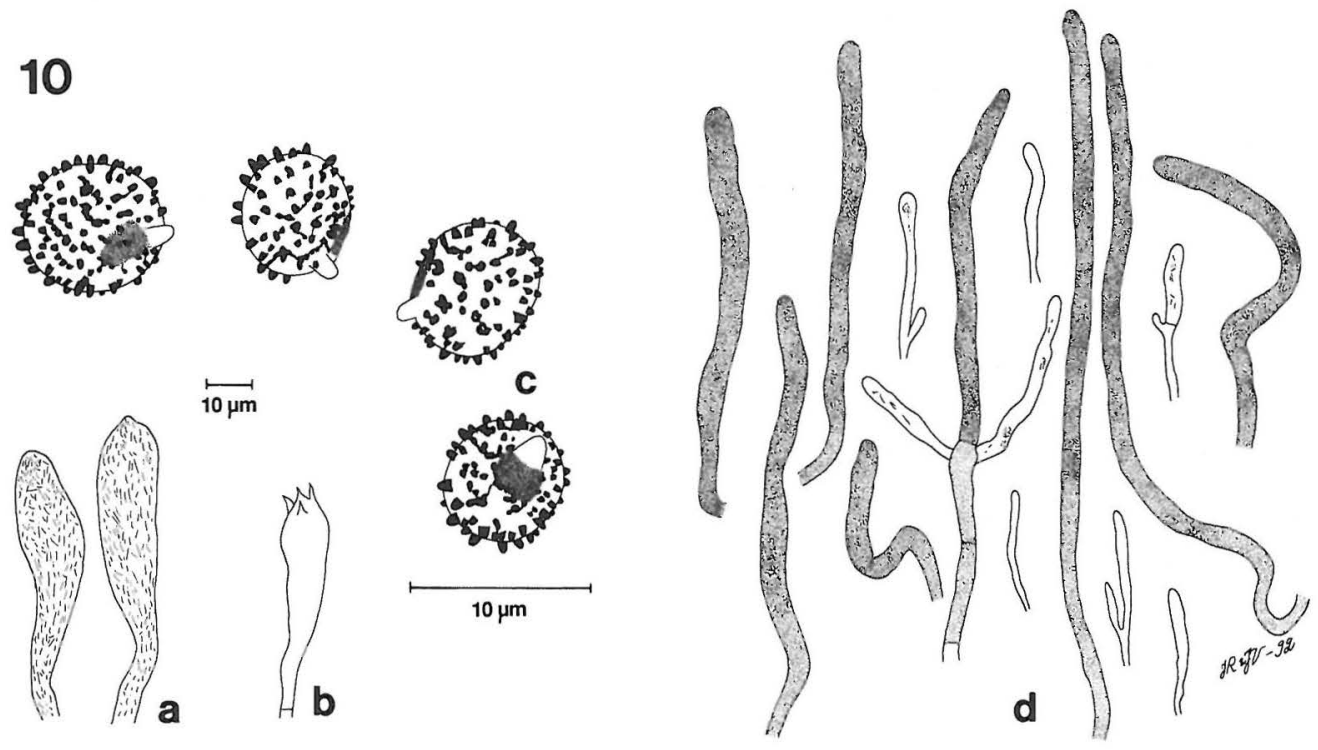

Fig. 10a-d. Microscopical details of Russula intermedia (from syntype of $R$. aurantiolutea, NY). - a) hymenial cystidia, b) basidia, c) spores, d) elements of pileipellis. Scales: spores x 2000, others x 500.

rarely, by Michael et al. (1983), Rayner (1985), Knudsen \& Stordahl (1992), and Singer (1938) describes it for $R$. mesospora. Perhaps there has been some confusion with a species rare in Europe, $R$. tenuiceps Kauffman. To us, it is a more slender red to orange species with stipe often white but sometimes of a red shade. Its spores are in mass somewhat paler than those of $R$. intermedia. The species differs microscopically from $R$. intermedia in its more ellipsoidal spores $(7-9 \times 6-8 \mu \mathrm{m})$ and shorter and broader dermatocystidia. Moreover, it is much more acrid than $R$. intermedia, which, as Schäffer (1938) had noted in the protologue of $R$. pulcherrima, is "magis amaro quam acri".

We have seen $R$. tenuiceps in various parts of Finland, but fairly rarely. Most often it grows with Betula. Ohenoja (1992) has reported the species from northern Finland, Perä-Pohjanmaa, Keminmaa, Kallinkangas area. Further, some specimens included in an earlier map of $R$. lundellii in Finland (Vauras 1981) can now be identified as $R$. tenuiceps. A photograph of the species was published recently as $R$. mesospora (Dähncke
1993: 933). When we checked from $\mathrm{C}$ and UPS four syntypes of $R$. pulcherrima S.Lundell \& Jul. Schäff., collected by S. Lundell in 1933, 1936 and 1937 we found each of them to include one fruit body of $R$. tenuiceps. However, the majority of fruit bodies of these collections represented $R$. intermedia, to which species the protologue of $R$. pulcherrima fits excellently. Apparently the exsiccate of Fungi Exs. Suec. Ups. 723 is a mixed collection. The exsiccate specimen housed in UPS includes, in addition to one fruit body of $R$. tenuiceps, one fruit body and three halves of $R$. intermedia. This last mentioned part of the specimen is selected here to represent the lectotype of $R$. pulcherrima S.Lundell \& Jul.Schäff.

$R$. intermedia is fairly common in fertile forests of southern, central and eastern Finland, especially in eastern Finland, where it flourishes in forests slashed and burnt a century ago. Today, such forests often are mixed forests dominated by Betula and Picea abies. R. intermedia grows with Betula, but is rare in Northern Finland (Fig. 11). It is worth adding that we have found $R$. intermedia in two localities 
close to the Mustiala College of Agriculture, where P.A. Karsten lived and taught (1985 Vauras 1698, KUO; 1990 Vauras 5073, TUR, TURA, UPS; 1991 Vauras 6194, TURA).

On the basis of our study of two syntype specimens of $R$. aurantiolutea and a close reading of Shaffer's (1970) paper, we interpret this North American species as conspecific with $R$. intermedia. We were unable to find any microscopical differences between the two species. However, according to the diagnoses by Kauffman (1909) and Shaffer (1970), the pileus of $R$. aurantiolutea is dominantly yellow, whereas the pileus of $R$. intermedia in Finland is dominantly red (like $R$. paludosa Britzelm.), though we have also seen fruit bodies of $R$. intermedia with a yellow to orange to even nearly white pileus in Finland. Some uncertainty remains, however, because Kauffman (1909) states that $R$. aurantiolutea is "often very acrid" and has "8-9 micr." long spores.

Our measurements of a syntype specimen of $R$. aurantiolutea, wrongly indicated as an isotype on the label (USA. Michigan: Houghton, 15.VIII.1906 C.H. Kauffman; NY), gave the following results. Spores 6.5-7.5 ×6-6.5 $\mu \mathrm{m}$, mean value 7.0 $6.1 \mu \mathrm{m}$, $\mathrm{Q}=1.1-1.2(-1.25)$, average $\mathrm{Q}=1.15$. Basidia $45-51$ x 10-12 $\mu \mathrm{m}, 4$-spored. Hymenial cystidia 11-14 $\mu \mathrm{m}$ broad. Apical cells of pileipellis $2-4 \mu \mathrm{m}$ broad. Dermatocystidia 4-7 $\mu \mathrm{m}$ broad, long, cylindrical, without septa (Fig. 10). Another syntype collection studied: locality not indicated, 6.VIII.1906 Kauffman (MICH). In the protologue Kauffman (1909) states that he has seen $R$. aurantiolutea in collections made in "July, August and September. Earlier in southern Michigan." For this reason the specimen cited by Shaffer (1970) can not be the holotype. Shaffer's citation must, however, be treated as an unintentional lectotypification (Art. 8.3).

Russula groenlandica Ruots. \& Vauras, nom. et stat. nov. - Fig. 12

Russula claroflava var. viridis Knudsen \& T.Borgen, Persoonia 14: 514. 1992. — Type: Greenland. Søndre Strømfjord, Hasselfjeld, with Betula nana, alt. 100 m, 19.VIII.1987 Hennig Knudsen 87.230 (C, holotype; examined).

After examining one freeze-dried fruit body of the holotype and four additional specimens of Russula claroflava var. viridis, determined by $\mathrm{H}$. Knudsen, we concluded that this taxon is worthy of the rank of species. Already in the original description,

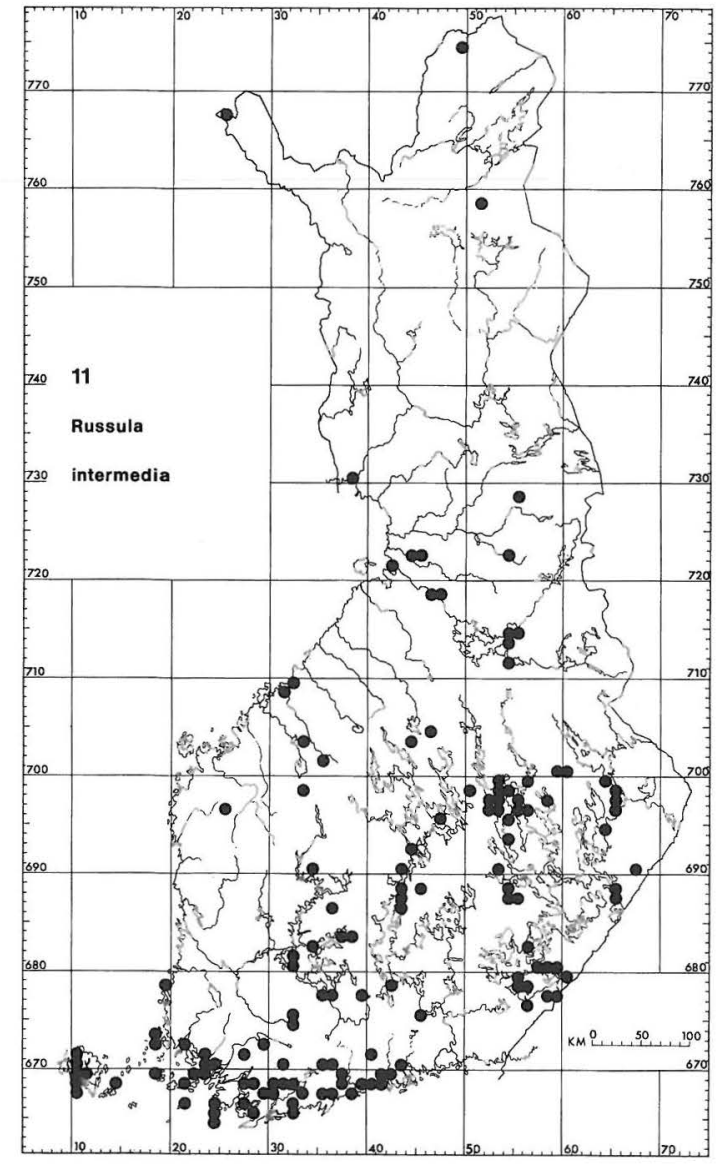

Fig. 11. Distribution of Russula intermedia in Finland according to the specimens examined.

Knudsen \& Borgen (1992) reported two interindependent characters that distinguish $R$. claroflava var. viridis from $R$. claroflava var. claroflava: the intense green colour of the pileus and the broader spores. Our microscopical study revealed that the taxa also differ in spore ornamentation; in average length of spores, hymenium cystidia and basidia; and in pileipellis (Fig. 12, Table 2). The colour of $R$. groenlandica spores in mass is not yet exactly known. Because the name Russula viridis has been appropriated earlier (Velenovský 1920-1922, Cleland 1934), the present species needed a new name. 

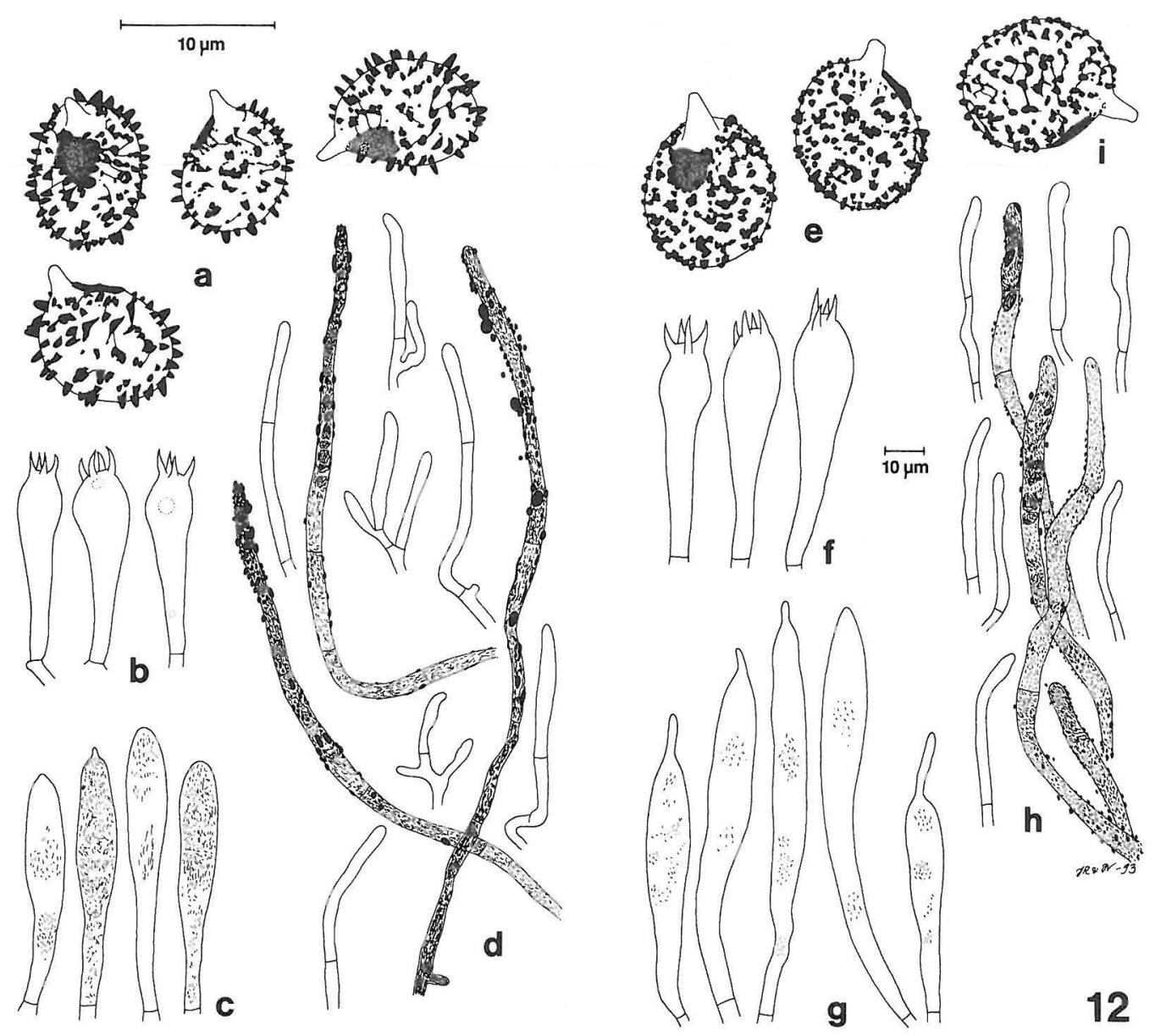

Fig. 12a-i. Microscopical details. - a-d. Russula claroflava (Finland, Pohjois-Savo, Vehmersalmi, Ruotsalainen 1269F, TURA). a) spores, b) basidia, c) hymenial cystidia, d) elements of pileipellis. - e-i. R. groenlandica. e, i) spores, f) basidia, g) hymenial cystidia, h) elements of pileipellis. (e-h from holotype of $R$. claroflava var. viridis, C; i from Knudsen, Borgen \& Petersen 636, C). Scales: spores x 2000, others x 500.

Microscopically $R$. groenlandica shows affinity to $R$. pubescens A. Blytt. Both species have fairly similar ornamentation on the spores, and their encrusted fuchsinophile hyphae of pileipellis lie in clusters. $R$. pubescens, which has a wide boreal distribution, is a greying species closely related to $R$. vinosa Lindblad (Ruotsalainen \& Vauras 1991).

In Finland, $R$. claroflava Grove is one of the most easily recognized Russula species, characterized by its beautiful yellow pileus, greying flesh when old, and mild taste. When growing in shady sites, the pileus often is of mixed yellow and yellow-brown colour; but the greenish shade is much rarer and never intense.

\section{Specimens examined}

Canada. Newfoundland, Schaefferville, $30 \mathrm{~km} \mathrm{~S}$ of the town, 15.8.1963 Kallio 509 (TUR).

Greenland. Kangilineq, 28.VIII.1983 Borgen 84.195 (C). Narssarssuaq, 21.VIII.1983 Knudsen, Borgen \& Petersen 636 (C), 9.VIII.1984 Knudsen \& Laessøe 84.515 (C). 
Table 2. Comparison of some characters of $R$. clarofava and $R$. groenlandica. Spore measurements are based on 100 spores from five collections of $R$. claroflava (spores from spore prints), and 50 spores from the holotype of $R$. claroflava var. viridis (spores lying on lamellae).

\begin{tabular}{lll}
\hline & $R$. claroflava & $R$. groenlandica \\
\hline $\begin{array}{l}\text { Pileus colour } \\
\text { mainly }\end{array}$ & yellow & green \\
$\begin{array}{l}\text { Spores } \\
\text { ornamentation }\end{array}$ & $\begin{array}{l}\text { warts mostly narrow, } \\
\text { relatively acute }\end{array}$ & warts broader, blunt \\
Size & $8-9.5(-10) \times$ & \\
& $6.5-7.5(-8) \mu \mathrm{m}$ & $8.5-10.5(-11) \times$ \\
$\overline{\mathrm{X}}$ & $8.6-\underline{8.8}-9.1 \times$ & $(7-) 7.5-8.5(-9) \mu \mathrm{m}$ \\
& $6.7-\underline{7.0}-7.1 \mu \mathrm{m}$ & $9.3 \times 8.0 \mu \mathrm{m}$ \\
$\mathrm{Q}$ & $(1.15-) 1.2-1.35(-1.4)$ & $(1.05-) 1.1-1.25(-1.3)$ \\
Average Q & $1.24-\underline{1.26}-1.29$ & 1.17 \\
Basidia & $39-57 \times 9-17 \mu \mathrm{m}$ & $50-69 \times 11-18 \mu \mathrm{m}$ \\
Hymenium cystidia & $61-83 \times 9-13 \mu \mathrm{m}$ & $76-111 \times 10-17 \mu \mathrm{m}$ \\
$\begin{array}{l}\text { Encrusted } \\
\text { fuchsinophile }\end{array}$ & narrower, mostly even & \\
hyphae of pileipellis & & broader, relatively uneven \\
Location & mainly diffuse & in clusters \\
Encrustation & relatively diffuse, as round granules & on hyphae, often plate-like \\
\hline
\end{tabular}

Søndre Strømfjord, Hasselfjeld, 19.VIII.1987 Knudsen 87.230 (holotype, C); Ravneklippen, 18.VIII.1946 M. Lange (C).

Norway. Oppland: Sör-Fron, syd for Langfjorna, 25.VII.1980 Stordal 20682 (O).

Specimens of $R$. claroflava used in microscopical measurements (Table 2): Finland. Ahvenanmaa: Lemland, Flaka, 10.IX.1992 Vauras 7409 (TURA). Varsinais-Suomi: Kustavi, Rahi, Leonsaari, 14.IX.1990 Vauras 5169 (TURA). Perniö, Mathildedal, 14.VIII.1991 Vauras 5753 (TURA). Pohjois-Savo: Vehmersalmi, Putroniemi, 14.VII.1989 Ruotsalainen 1269 F (TURA). Oulun Pohjanmaa: Oulu, Sanginsuu, Peräkylä, 19.VIII.1989 Vauras 3617 (TURA).

Acknowledgements. Our sincere thanks are due to the curators of herbaria which sent us material on loan. We are very grateful to Dr. Ilkka Kytövuori (Helsinki) for placing his specimens of Russula intermedia and R. olivobrunnea at our disposal. We are indebted to Dr. Mauri Korhonen (Helsinki) for helping us during the study of the neotype material of $R$. intermedia and for valuable taxonomic discussions. Dr. Gerhard Weber (Schwarmstedt, Germany) and Prof. Teuvo Ahti (Helsinki) kindly helped us with nomenclatural problems.
We thank Dr. Seppo Huhtinen (Turku) for critical reading of the manuscript in many phases of it, and Dr. Ilkka Kytövuori and Dr. Harri Harmaja (Helsinki) for criticism on an earlier draft of it.

\section{References}

Cailleux, A. 1981: Code des couleurs des sols. - Boubée.

Cleland, J.B. 1934: Toadstools and mushrooms and other larger fungi of South Australia. Vol. 1. $-178 \mathrm{pp}$. Government Printer, Adelaide.

Dähncke, R.M. 1993: 1200 Pilze in Farbfotos. - 1179 pp. AT Verlag, Aarau.

Greuter, W. \& McNeill, J. 1993: Synopsis of proposals on Botanical Nomenclature - Tokyo 1993. A review of the proposals concerning the International Code of Botanical Nomenclature submitted to the XV International Botanical Congress. - Taxon 42:191271.

Holmgren, P.K., Holmgren, N.H. \& Barnett, L.C. 1990: Index herbariorum 1. The herbaria of the world. 8th ed. - Regnum Vegetabile 120:1-693. 
Karsten, P.A. 1888: Symbolae ad mycologiam fennicam. - Medd. Soc. Fauna Flora Fennica 16:37-45.

Karsten, P.A. 1891: Kritisk öfversigt af Finlands basidsvampar. Tillägg 1. - Bidrag Kännedom Finlands Natur Folk 51:177-230.

Karsten, P.A. 1894: Kritisk öfversigt af Finlands basidsvampar. Tillägg 2. - Bidrag Kännedom Finlands Natur Folk 54:155-186.

Karsten, P.A. 1895: Fragmenta mycologica. 43. Hedwigia 34:7-9.

Kauffman, C.H. 1909: Michigan species of Russula. Rep. Mich. Acad. Sci. 11:55--91.

Knudsen, H. \& Borgen, T. 1992: New and rare taxa of Russula from Greenland. - Persoonia 14:509-517.

Knudsen, H. \& Stordal, J. 1992: Russula Pers. In: Hansen, L. \& Knudsen, H. (eds.), Nordic Macromycetes. 2:374-400. - Nordsvamp, Copenhagen.

Korhonen, M. \& Vauras, J. 1986: Suomen haperoista. Sienilehti 38:58-69.

Küppers, H. 1981: DuMont's Farben-Atlas. 2nd ed. 163 pp. DuMont Buchverlag, Köln.

Michael, E., Hennig, B. \& Kreisel, H. 1983: Handbuch für Pilzfreunde. 5. 2nd ed. - 408 pp. Gustav Fischer Verlag, Stuttgart.

Moser, M. 1978: Über eine subboreale and eine subalpine Russula Art. - Sydowia 31:97-102.

Ohenoja, E. 1992: Keminmaan Kallinkankaan suursienistö. - Lutukka 8:125-133.
Rayner, R.W. 1985: Keys to the British species of Russula. 3rd ed. - 99 pp. The British Mycological Society.

Ruotsalainen, J. \& Vauras, J. 1990: Finnish records of the genus Russula. The new species R. olivina and R. taigarum. - Karstenia 30:15-26.

Ruotsalainen, J. \& Vauras, J. 1991: Lehtoviinihapero (Russula pubescens) Suomessa. - Sienilehti 43:3942.

Schäffer, J. 1938: Beitrag zur Russula-Forschung. 2. Ann. Mycol. 36:27-43.

Shaffer, R.L. 1970: Notes on the subsection Crassotunicatae and other species of Russula. Lloydia 33:49-96.

Singer, R. 1938: Contribution á l'étude des Russules (1). 3. Quelques Russules américaines et asiatiques. Bull. Soc. Mycol. France 54:132-177.

Ulvinen, T., Ohenoja, E., Ahti, T. \& Alanko, P. 1981: A check-list of the fungi (incl. lichens) of the Koillismaa (Kuusamo) biological province, N.E. Finland. Oulanka Reports 2:1-63.

Vauras, J. 1981: Koivunlehtohapero (Russula lundellii). - Sienilehti 33:24-27.

Velenovský, J. 1920-1922: České Houby. — 950 pp. Praha.

Received on 26 May 1993 